\title{
PENGARUH PENGGUNAAN MEDIA PEMBELAJARAN DAN MOTIVASI BERPRESTASI TERHADAP HASIL BELAJAR GEOGRAFI SISWA SMP NEGERI KECAMATAN SINGKIL
}

\author{
Maya Seroja dan Ibrahim Gultom ${ }^{2}$ \\ SMP Negeri Kecamatan Singkil ${ }^{1}$ dan Universitas Negeri Medan ${ }^{2}$ \\ bunga_mukhaira@yahoo.co.id ${ }^{1}$
}

\begin{abstract}
Abstrak: Penelitian ini bertujuan untuk mengetahui : (1) hasil belajar Geografi yang diperoleh siswa yang diajarkan dengan menggunakan media pembelajaran Globe dengan siswa yang diajarkan menggunakan media pembelajaran Peta, (2) perbedaan hasil belajar Geografi siswa yang memiliki motivasi berprestasi tinggi dan hasil belajar Geografi siswa yang memiliki motivasi berprestasi rendah, dan (3) interaksi antara media pembelajaran dengan motivasi berprestasi terhadap hasil belajar Geografi. Metode penelitian menggunakan metode quasi eksperimen dengan desain penelitian faktorial 2x2. Teknik analisa data yang digunakan teknik ANAVA dua jalur pada taraf signifikan $\alpha=0,05$. Tes perbedaan antar sel dilakukan dengan menggunakan uji Scheffe. Hasil penelitian diperoleh : (1) hasil belajar Geografi siswa yang diajarkan dengan menggunakan media pembelajaran peta lebih tinggi dari diajarkan dengan menggunakan media pembelajaran Globe dengan $F_{\text {hitung }}=5,94>F_{\text {tabel }}=4,02$, (2) hasil belajar Geografi siswa yang memiliki motivasi berprestasi tinggi lebih tinggi dari yang memiliki motivasi berprestasi rendah dengan $F_{\text {hitung }}=162,23>F_{\text {tabel }}=4,02$, (3) terdapat interaksi antara media pembelajaran (peta dan globe) dengan motivasi berprestasi terhadap hasil belajar Geografi dengan $F_{\text {hitung }}=14,08>F_{\text {tabel }}$ $=4,02$.
\end{abstract}

Kata Kunci: media pembelajaran, motivasi berprestasi, hasil belajar geografi

Abstract: This study aims to determine: (1) the results of study Geography obtained students taught using instructional media Globe with students taught using instructional media map, (2) differences in learning outcomes Geography student who has high achievement motivation and learning outcomes Geography students who have low achievement motivation, and (3) the interaction between media with achievement motivation on learning outcomes Geography. The research method using quasi-experimental design with a $2 \times 2$ factorial study. Data analysis technique used ANOVA technique two lanes at significant level $\alpha=0.05$. Tests the difference between cells is done by using the Scheffe test. The results were obtained: (1) Geography student learning outcomes are taught using instructional media map is higher than taught using instructional media Globe with Fhitung $=5.94>F$ table $=4.02$, (2) the learning outcomes of students who have the motivation Geography High achievement is higher than that have low achievement motivation with Fhitung $=162.23>F$ table $=4.02$, (3) there is interaction between learning media (maps and globes) and achievement motivation for learning outcomes Geography with Fhitung $=14.08>$ Ftable $=4.02$.

Keywords: media learning, achievement motivation, learning outcomes geography

\section{PENDAHULUAN}

Geografi merupakan salah satu cabang Ilmu Pengetahuan Sosial, yang sebagian besar materinya lebih bersifat teoretis dan teks yang siswanya tidak hannya dituntut menghafal tetapi siswa diharapkan mampu memahami materi yang dipelajari dengan baik, sehingga mata pelajaran geografi kurang menarik oleh siswa yang biasanya oleh guru dalam bentuk ceramah atau metode konvensional.
Berdasarkan hasil observasi awal peneliti di SMP Negeri 1 Singkil dan SMP Negeri 2 Singkil, selama pembelajaran berlangsung guru mata pelajaran geografi lebih cenderung menggunakan strategi kovensional dalam menyampaikan materi pelajaran. Pembelajaran berpusat pada guru (teacher centered). Guru lebih banyak menggunakan metode ceramah dan sekali-sekali tanya jawab tanpa diiringi dengan media pembelajaran 
sedangkan siswanya kurang siap menerima pelajaran, sehingga mereka hanya mencatat fakta-fakta yang diterangkan guru. Pembelajaran ini membuat siswa hanya menerima dan tidak melatih kemampuan untuk belajar aktif. Hal ini terlihat dari seringnya siswa minta izin keluar pada saat pelajaran berlangsung. Ini mengakibatkan materi yang disampaikan tidak sepenuhnya diserap oleh siswa. Pada akhirnya dengan menggunakan metode ceramah konvensional dimana kurangnya interaksi siswa secara aktif berakibat pada rendahnya hasil belajar siswa atau berada di bawah kriteria ketuntasan minimal (KKM) yang telah ditetapkan oleh pihak sekolah atas usulan guru mata pelajaran.

Proses pembelajaran berbasis kompetensi telah mengubah paradigma belajar dari "guru dan apa yang akan diajarkannya " ke siswa dan "apa yang akan dilakukan" sesuai pandangan belajar konstruktivisme yang beranggapan bahwa pengetahuan itu hasil konstruksi melalui pengalaman belajar siswa. Selanjutnya Romiszowski (1983) mengatakan bahwa seorang guru harus menyusun perilaku, memperhatikan respon siswa, dan memberikan penguatan atau tindakan atau respon siswa. Maka, mengajar merupakan suatu kegiatan untuk dapat mempermudah meraih keberhasilan. Dalam hal ini, pembelajaran ditandai dengan keaktifan guru dan siswa dalam suatu proses, guru merupakan motor penggerak bagi siswa agar dapat belajar secara efektif. Pembelajaran harus menekankan pada bagaimana membelajarkan siswa, bukan pada apa yang dipelajari siswa. Hal ini berarti bahwa pembelajaran merupakan suatu tindakan yang dilakukan oleh guru untuk menjadikan siswa untuk belajar.

Berdasarkan kenyataan adanya perbedaan individual, tidak semua siswa dapat mencapai tujuan yang diharapkan. Terhadap siswa yang masih dinilai belum berhasil mencapai tujuan, guru bertanggung jawab untuk membantu agar tercapai hasil belajar melalui perbaikan proses belajar. Keberhasilan seorang guru terletak pada kemampuannya untuk melaksanakan proses belajar mengajar sebaikbaiknya sehingga siswa mencapai tujuan yang diharapkan. Dengan menerapkan strategi pembelajaran melalui penggunaan media pembelajaran yang tepat diharapkan dapat membantu siswa dalam meningkatkan hasil belajarnya.

Belajar selalu berhubungan dengan perubahan tingkah laku seseorang terhadap sesuatu situasi tertentu yang disebabkan oleh pengalaman yang berulang- ulang dalam situasi tersebut. Perubahan tersebut tidak berhubungan atas dasar adanya kecenderungan respon pembawaan, kematangan atau keadaan sesaat seseorang. Ini berarti belajar menyangkut aspek kepribadian, baik fisik maupun psikis seperti perubahan pengertian, pemecahan masalah, keterampilan, kecakapan, kebiasaan atau sikap (Hilgard and Bower, 1981).

Belajar pada dasarnya adalah suatu proses aktivitas mental seseorang dalam berinteraksi dengan lingkungannya sehingga menghasilkan perubahan tingkah laku yang bersifat positif baik perubahan dalam aspek pengetahuan, sikap maupun psikomotor. Dikatakan positif, karena perubahan perilaku itu bersifat adanya penambahan dari perilaku sebelumnya yang cenderung menetap yaitu tahan lama dan tidak mudah dilupakan.

Menurut Cronbach (1979), belajar adalah suatu perubahan tingkah laku sebagai hasil dari pengalaman. Begitu juga Lester D. Crow dalam Sagala (2007), belajar ialah upaya untuk memperoleh kebiasaan-kebiasaan, pengetahuan dan sikap-sikap. Lebih lanjut dikatakan bahwa proses perubahan tersebut secara relatif untuk memperoleh perubahan permanen dalam pemahaman, sikap, penetahuan, imformasi, kemampuan dan keterampilan melalui pengalaman.

Belajar yang berkenaan dengan hasil, Gagne dalam Sanjaya (2006) juga mengemukakan terdapat lima tipe hasil belajar yaitu : (1) belajar kemahiran intelektual, (2) belajar informasi verbal, (3) belajar mengatur kegiatan intelektual, (4) belajar sikap, (5) belajar keterampilan motorik. Hasil belajar digunakan oleh guru untuk dijadikan ukuran atau kriteria dalam mencapai suatu tujuan pendidikan. Hal ini dapat tercapai apabila siswa sudah memahami belajar dengan diiringi oleh perubahan tingkah laku yang lebih baik lagi (Munawar, 2009).

Bloom (1976) menyatakan bahwa hasil belajar seseorang ditunjukkan pada proses perkembangan kemampuan dalam diri dapat dikategorikan ke dalam tiga ranah yakni : (a) kognitif, (b) afektif, (c) psikomotorik.

Munawar (2009) mengemukakan, kemampuan pada ranah kognitif berkenaan dengan hasil belajar intelektual yang terdiri dari 6 aspek yaitu pengetahuan, pemahaman, penerapan, analisis, sintesis dan penilaian. Kemampuan ranah afektif berkenaan dengan sikap dan nilai. Ranah afektif meliputi lima 
jenjang kemampuan yaitu menerima, menjawab atau reaksi, menilai, organisasi dan karakterisasi dengan suatu nilai atau kompleks nilai. Kemampuan pada ranah psikomotorik meliputi persepsi gerakan, kesiapan gerakangerakan terbimbing, dan gerakan terbiasa.

Menurut Nasution dan Suryanto (2002), proses penilaian hasil belajar yang berhubungan dengan kognitif biasanya diukur dengan menggunakan tes, sedangkan penilaian yang berhubungan aspek afektif dan psikomotorik biasanya diukur dengan menggunakan alat ukur yang disebut non- tes.

Richard Hartshorne dalam Sumaatmajda (2001) mengemukakan Geography is that discipline that seeks to describe and interpret the variable character from place to place of the earth as the world of man. Pada batasan ini Hartshone menekankan kepada karakter variabel dari suatu tempat ke tempat lainnya sebagai dunia tempat kehidupan manusia. Dalam hal ini geografi sebagai bidang ilmu mencari penjelasan dan interpretasi tentang karakter tersebut sebagai hasil interaksi faktor- faktor geografi yang mencirikan tempat- tempat di permukaan bumi sebagai dunia kehidupan manusia.

Pembelajaran geografi hakikatnya adalah pembelajaran mengenai gejala- gejala geografi yang tersebar di permukaan bumi. Untuk memberi citra tentang penyebaran dan lokasi gejala- gejala tersebut kepada siswa tentu tidak hanya dengan menggunakan metode ceramah, tanya jawab, dan diskusi melainkan harus ditunjukkan dan didemonstrasikan melalui media pembelajaran.

$$
\text { Menurut AECT }
$$

(Association

Education and Communication Technology) dalam Arsyad (2010) bahwa media sebagai segala bentuk yang digunakan untuk menyalurkan informasi atau pesan. Kata segala bentuk memberi makna bahwa yang dimaksud dengan media tidak terbatas pada jenis media tertentu saja; melainkan apapun yang dapat digunakan untuk menyalurkan atau menjelaskan atau memperjelas suatu pesan dapat disebut sebagai media.

Disamping itu, sebagai sistem penyampai atau pengantar, media yang sering diganti dengan kata mediator menurut Fleming dalam Arsyad (2010) adalah penyebab atau alat yang turut campur tangan dalam dua pihak dan mendamaikannya. Dengan istilah mediator, media menunjukkan fungsi atau perannya, yaitu mengatur hubungan yang efektif antara dan pihak utama dalam proses belajar siswa dan isi pelajaran.

$$
\text { Gagne dan Briggs (1992) secara }
$$
implisit mengatakan bahwa media pembelajaran meliputi alat yang secara fisik digunakan untuk menyampaikan isi materi pengajaran. Pendapat ini lebih memfokuskan bahwa media dapat diartikan sebagai alat yang digunakan dalam proses pembelajaran.

Dalimunthe (2004) menjelaskan media pembelajaran secara keseluruhan adalah segala benda dan alat yang digunakan untuk membantu pelaksanaan proses belajar mengajar Ilmu Pengetahuan Sosial (IPS) seperti slide, epidiaskup, proyektor, peta, globe, grafik, diagram, potret, gambar, maket, film, tape recorder, radio, dan lain sebagainya. Mediamedia tersebut tidak hanya sekedar memperagakan hal- hal yang harus diragakan, melainkan digunakan untuk mengungkapkan lebih jauh pokok- pokok dan konsep yang harus dibina pada diri siswa.

Hamalik (2006) menyatakan, guru harus memiliki pengetahuan dan pemahaman yang cukup tentang media pembelajaran, yang meliputi : (1) media sebagai alat komunikasi guna lebih mengefektifkan proses belajar mengajar, (2) fungsi media dalam rangka mencapai tujuan pendidikan, (3) seluk- beluk proses belajar, (4) hubungan antara metode mengajar dan media pendidikan, (5) nilai atau manfaat media pendidikan dalam pengajaran, (6) pemilihan dan penggunaan media pembelajaran, (7) berbagai jenis alat dan teknik media pembelajaran, (8) media pembelajaran dalam setiap mata pelajaran, (9) usaha inovasi dalam media pembelajaran.

Media pembelajaran digunakan secara bergantian dengan istilah alat bantu atau media komunikasi seperti yang dikemukakan oleh Hamalik (2006), dimana ia menyatakan bahwa media komunikasi akan berjalan lancar dengan maksimal apabila menggunakan alat bantu yang disebut media komunikasi, dan media pembelajaran adalah alat, metode dan teknik yang digunakan dalam rangka lebih mengefektifkan komunikasi dan interaksi antara guru dengan siswa dalam proses pembelajaran di sekolah.

Namun demikian, media bukan hanya berupa alat atau bahan saja, tetapi hal- hal lain yang memungkinkan siswa dapat memperoleh pengetahuan. Gerlach dan Ely dalam Sanjaya (2006) menyatakan A medium, conceived is any person, material or event that establish condition which enable the learner to acquire 
knowledge, skill, and attitude. Menurut Gerlach secara umum media itu meliputi orang, bahan, peralatan, atau kegiatan yang menciptakan kondisi yang memungkinkan siswa memperoleh pengetahuan, keterampilan dan sikap. Dalam pengertian ini, guru, buku teks dan lingkungan sekolah merupakan media.

Menurut Sanjaya (2006), media pembelajaran memiliki fungsi dan peran untuk : (a) menangkap suatu objek atau peristiwaperistiwa tertentu, (b) memanipulasi keadaan, peristiwa, atau objek tertentu, dan (c) menambah gairah dan motivasi belajar siswa.

Menurut Sardiman (2010), menyatakan media pembelajaran yang lazim dipakai dalam kegiatan belajar mengajar khususnya di Indonesia yaitu : (a) media proyeksi, seperti proyeksi diam, film bingkai, media transparansi, proyeksi tak tembus pandang, mikrofis, film, film gelang, televisi dan video, (b) media grafis, seperti : gambar, foto, sketsa, diagram/ skema, bagan/ chart, grafik, kartun, poster, peta/ globe, papan panel dan papan buletin, (c) media audio, seperti : radio, alat perekam pita magnetik.

Peta merupakan konsep (round earth on the flat paper) dan hakikat dasar pada geografi dan pembelajaran geografi. Oleh karena itu, mengajarkan dan mempelajari geografi tanpa peta, tidak akan membentuk citra dan konsep yang baik pada diri anak didik yang mempelajarinya (Sumaatmadja, 2001).

Adiwuyono (2008) mendefinisikan peta sebagai suatu presentasi di atas bidang datar baik seluruh atau sebahagian permukaan bumi yang dilihat dari atas dan diperkecil dengan perbandingan tertentu.

Peta dapat diartikan sebagai gambaran sebagian atau seluruh wilayah permukaan bumi dengan berbagai kenampakannya pada suatu bidang datar yang diperkecil menggunakan skala tertentu (Gunawan, 2003). Pada sebuah peta terdapat berbagai unsur wilayah di permukaan bumi seperti gunung, sungai, kota, jalan raya, jalan kereta api, dataran rendah, dataran tinggi, dan lainnya yang digambarkan dengan simbol- simbol untuk memudahkan orang menggunakannya. Peta adalah alat bantu yang memudahkan pembacanya mengetahui informasi dari beragam hal yang ada di bumi (Wibowo, 2005). Secara sederhana, peta diartikan sebagai gambar sebagian atau seluruh permukaan bumi pada bidang datar yang diperkecil dengan menggunakan skala tertentu dan dilengkapi dengan simbol- simbol.
Hartono (2010) menjelaskan peta berfungsi memberikan informasi kepada pembacanya mengenai : (1) letak relatif suatu daerah terhadap daerah lainnya di permukaan bumi. Letak dapat dibedakan seperti: letak astronomis, letak geografis, dan letak administrasi, (2) ukuran wilayah, misalnya: jarak (panjang), lebar dan luas wilayah, isi atau volume waduk, volume tanah yang harus digali, dan arah atau sudut, (3) kondisi fisik dan nonfisik suatu daerah, misalnya jumlah penduduk, kepadatan bangunan, dan sebagainya, (4) sebagai alat bantu penelitian lapangan, operasi militer, jelajah alam, dan sebagainya.

Selanjutnya Wardiyatmoko (2009) menyatakan, media peta berfungsi untuk memberikan informasi sebagai berikut : (1) menunjukkan dan menggambarkan bentang alam dan budaya, (2) memberikan gambaran fisiografis secara umum, (3) memperlihatkan ukuran suatu objek geografi di peta, (4) mengetahui keadaan sosial, ekonomi, budaya di suatu daerah, (5) sebagai media pembelajaran untuk mempelajari muka bumi dan fenomena geografi di dalamnya, (6) sebagai alat bantu analisis dalam suatu penelitian.

Guru dapat berperan membimbing siswa dalam menggunakan media peta secara bermakna yaitu siswa tidak hanya sekedar menghafal fakta atau data tertentu atau mengenai peristiwa, tetapi siswa dapat belajar melakukan pengamatan langsung. Hal ini sesuai dengan yang dikemukakan oleh Dalimunthe (2004) bahwa tujuan Ilmu Pengetahuan Sosial (IPS) yang perlu dilatihkan kepada siswa dalam proses belajar mengajar seperti : (1) keterampilan berfikir (thinking skill), (2) keterampilan akademik/ studi, dan (3) keterampilan sosial.

Menurut Sumaatmadja (2001) pembentukan citra dan konsep pada diri siswa untuk dapat meningkatkan kognitif, afektif, dan psikomotor siswa haruslah memanfaatkan media peta. Proses tersebut mulai dari pengenalan, pembacaan (map reading), pemilihan, dan pembuatan peta. Sesuai dengan tingkat umur dan jenjang pendidikan, anak didik dibimbing mengenal peta, membaca peta, memilih peta hingga membuat peta. Melalui proses ini, tidak hanya kemampuan kognitif yang terbina, keterampilan membacamenggunakan- membuat peta juga terkembangkan.

Lebih lanjut Sumaatmadja (2001) mengatakan kesadaran dan penghayatan anak didik terhadap gejala dan permasalahan yang 
terjadi dalam kehidupan di permukaan bumi juga dapat terbina pada diri mereka melalui pemanfaatan peta. Dengan demikian, akan terbina kemampuan memanfaatkan sumber daya lingkungan secara rasional sesuai dengan tingkat kualitas kehidupan dan kualitas lingkungannya.

Globe sangat baik untuk menggambarkan kenampakan bumi. Bentuk fisik yang bulat dapat menggambarkan bumi mirip seperti aslinya. Dicantumkannya garis lintang dan bujur membantu pembaca untuk membayangkannya. Oleh karena itu globe memiliki kedudukan yang tidak kalah penting dibanding dengan peta dan atlas (Hartono, 2010)

Menurut Sumaatmadja (1996) globe merupakan model dan bentuk yang sangat mini dari bola bumi. Globe selain fungsinya sama dengan peta, lebih jauh lagi ia dapat membina dan mengembangkan citra serta konsep tentang waktu, iklim, musim dan gejala- gejala alam lainnya baik yang berkenaan dengan atmosfer, hidrosfer, maupun litosfer. Wardiyatmoko (2009) menyatakan kedudukan atau kecondongan globe sama dengan kedudukan sumbu bumi, yaitu sebesar $66^{1} 2^{\circ}$ terhadap bidang ekliptika (bidang horizontal) atau $23 \frac{1}{2}{ }^{\circ}$ terhadap bidang zenith (bidang vertikal).

Sugiharto (2010) mengemukakan globe adalah tiruan bola bumi yang diperkecil dan menggambarkan bentuk bumi yang sebenarnya. Sama halnya dengan peta, pada globe juga dicantumkan jari- jari garis lintang maupun garis bujur. Equator membagi bola bumi menjadi dua bagian utara dan selatan yang sama besar. Menurut Hidayat (2010), media penggambaran permukaan bumi selain pada peta juga sering kita temukan pada bidang lengkung/bola yang sering disebut dengan globe.

Globe adalah miniatur bumi. Dengan globe inilah suatu cara yang paling baik untuk memberikan gambaran dari konsep bumi bulat. Dengan globe, skala dan arah segala tempat dipermukaan bumi digambarkan secara benar. Menurut (Ruhimat, 2006) kebenaran globe menyebabkan globe digunakan untuk : (1) propaganda yang berkaitan dengan gempa bumi, arus samudera dapat diikuti secara baik pada globe, (2) dapat melihat hubungan lautanlautan, benua- benua, daerah kutub sehingga kita dapat melihat pemandangan yang tidak biasa dan hubungan yang tidak biasa, (3) konsep yang mendasari perbedaan waktu, iklim dan musim, pembagian zona waktu, arus samudera dapat dipahami secara baik, (4) sangat disarankan penggunaan globe pada langkah awal pelajaran pengetahuan sosial di sekolah, (5) pada setiap kelas sebaiknya mempunyai globe, (6) pada jenjang pendidikan tinggi globe juga sangat penting dalam kaitannya dengan matematika, geomatik, geografi, klimatologi, geodesi, oseanografi, seismologi, dan geoteknik.

Sumaatmadja (1996) mengatakan penggunaan dan pemanfaatan globe sebagai media pembelajaran geografi, dapat lebih meningkatkan kemampuan kognitif, afektif, dan psikomotor anak didik tentang relasi keruangan gejala- gejala geografi di permukaan bumi.

Lebih lanjut, Hartono (2010) menyatakan globe mempunyai banyak manfaat karena dapat digunakan sebagai alat ukur untuk : (1) menggambarkan dan memproyeksikan daerah-daerah di bumi yang mengalami gerhana dan proses terjadinya gerhana bulan dan gerhana matahari, (2) mengetahui perbedaan waktu berbagai tempat di bumi dengan pertolongan garis bujur, (3) mengetahui perbedaan iklim matahari dengan pertolongan garis lintang, (4) menggambarkan letak garis lintang, garis bujur, garis ekuator, letak kutub utara dan kutub selatan, letaj bujur $180^{\circ}$, dan letak benua-benua pada globe. Sebenarnya Garis-garis ini tidak terdapat pada bumi kita, tetapi garis-garis ini diperlukan karena sangat membantu dalam mempelajari letak kenampakan geografis bumi.

Lebih lanjut Suharyono dan Amien (1994) menyatakan pentingnya globe dapat dikemukakan sebagai contoh misalnya dalam menjelaskan tentang : (1) bagaimana terjadinya proses pergantian musim di Indonesia dalam kaitannya dengan perubahan kedudukan letak bumi terhadap matahari, (2) terjadinya peristiwa musim dingin (winter) di Jepang yang dipengaruhi oleh angin dingin yang berasal dari daratan pedalaman Asia, (3) bagaimana keterkaitan banjir tahunan yang selama ini melanda daerah Bojonegoro di Provinsi Jawa Timur dengan keberadaan Bengawan Solo serta bentang alam yang mengintarinya, (4) bagaimana keterkaitan antara kepadatan pulau Jawa dengan tanahnya yang subur akibat terjadinya rejuvenasi tanah yang terusmenerus dalam kaitannya dengan rangkaian gunung berapi di sepanjang pulau Jawa.

Sama halnya dengan peta, globe juga menggambarkan permukaan bumi. Namun dalam penggunaanya terdapat perbedaan 
dengan peta datar. Globe dapat memberikan informasi sebagai berikut (Ruhimat, 2006) ; Pertama, menunjukkan bentuk bumi. Globe bentuknya bulat, hampir mendekati bentuk bumi yang sebenarnya. Pada kenyataannya, bentuk bumi itu sendiri tidaklah bulat melainkan pada kedua kutubnya terjadi pemampatan. Kedua, menunjukkan sistem garis lintang dan bujur. Pada globe, garis lintang terlihat merupakan lingkaran- lingkaran yang sejajar dengan khatulistiwa. Makin jauh khatulistiwa, lingkaran- lingkaran tersebut semakin kecil dan pada kutub utara atau kutub selatan hanya merupakan sebuah titik saja. Demikian juga, garis bujur merupakan semua lingkaran yang melalui kutub utara dan kutub selatan yang besarnya sama. Ketiga, memperlihatkan gambaran permukaan bumi secara utuh. Pada peta datar permukaan bumi tidak dapat kita amati secara keseluruhan. Keempat, memperagakan gerak rotasi bumi. Gerak rotasi bumi dapat diperagakan melalui globe dengan memutar globe sesuai dengan arah perputaran bumi yang sebenarnya, yaitu dari arah barat ke timur. Kelima, memperagakan terjadinya siang dan malam. Dengan memutar globe sesuai dengan arah rotasi bumi, permukaan bumi secara bergantian akan menghadap matahari. Bagian permukaan bumi yang menghadap ke matahari mengalami siang dan bagian yang membelakangi matahari mengalami malam.

Motivasi dapat merupakan tenaga pendorong atau penarik yang menyebabkan tingkah laku ke arah suatu tujuan tertentu. McClelland (1995) mendefinisikan motivasi sebagai berikut : the reintegration by cue of a change in affective situation. Tiga istilah penting yang perlu dijelaskan dalam definisi ini adalah : reintegration, cue, dan affective situation. Istilah reintegration secara etimologis berarti membulatkan kembali atau membuat suatu kesatuan yang baru.

Sardiman (2009) menyatakan Motivation is an essensial condition of learning. Hasil belajar akan menjadi optimal, kalau ada motivasi. Makin tepat motivasi yang diberikan, akan berhasil pula pelajaran itu. Jadi, motivasi akan senantiasa menentukan intensitas usaha belajar bagi para siswa.

McDonald dalam Soemanto (1998) mengatakan motivasi adalah perubahan energi dalam diri seseorang yang ditandai dengan munculnya "feeling" dan didahului dengan tanggapan terhadap adanya tujuan. Motivasi akan menyebabkan terjadinya suatu perubahan energi yang ada pada diri manusia, sehingga akan bergayut dengan persoalan gejala kejiwaan, perasaan serta emosi, untuk kemudian bertindak atau melakukan sesuatu. Semua ini didorong karena adanya tujuan, kebutuhan atau keinginan.

Menurut Walgito (2004), motivasi merupakan keadaan dalam diri individu/organisme yang mendorong perilaku ke arah tujuan. Pada umumnya, motivasi mempunyai siklus (melingkar) yaitu motivasi timbul, memicu perilaku tertuju kepada tujuan (goal) dan akhirnya setelah tujuan (goal) tercapai motivasi itu terhenti. Tetapi itu akan kembali kepada keadaan semula apabila ada sesuatu kebutuhan lagi.

Martaniah dalam Fauziah (2010) memberi pengertian tentang motivasi berprestasi sebagai motif yang mendorong indivivu untuk berpacu dengan ukuran keunggulan. Ukuran keunggulan ini dapat menggunakan dirinya sendiri, orang lain dan dapat pula kesempurnaan tugas. Selanjutnya Motivasi berprestasi menurut McClelland dan Atkinson dalam Fauziah (2010) adalah upaya untuk mencapai sukses dengan berkompetisi dengan suatu ukuran keunggulan. Standar keunggulan yang dimaksud adalah berupa prestasi orang lain atau prestasi sendiri yang pernah diraih sebelumnya.

Menurut McClelland dan Atkinson dalam Djiwandono (2002), motivasi yang paling penting untuk psikologi pendidikan adalah motivasi berprestasi, dimana seseorang cenderung berjuang untuk mencapai sukses atau memilih suatu kegiatan yang orientasi untuk tujuan sukses atau gagal. Siswa-siswa yang termotivasi untuk berprestasi akan tetap melakukan tugas lebih lama daripada siswasiswa yang kurang berprestasi bahkan sesudah mereka mengalami kegagalan, dan menghubungkan kegagalannya dengan tidak atau kurang berusaha. Singkatnya, siswa yang termotivasi untuk mencapai prestasi ingin dan mengharapkan sukses. Dan jika gagal, mereka akan berusaha lebih keras lagi sampai sukses.

McClelland (1995) menjelaskan bahwa orang mempunyai motivasi untuk bekerja karena adanya kebutuhan untuk berprestasi. Dalam hal ini, maka motivasi merupakan fungsi dari tiga variabel, yaitu (1) harapan untuk melakukan tugas dengan berhasil, (2) persepsi tentang nilai tugas tersebut, dan (3) kebutuhan untuk keberhasilan atau sukses. Kebutuhan untuk berprestasi bersifat intrinsik dan relatif stabil dan seringkali motivasi 
berprestasi dinyatakan sebagai " $n$-ach". Orang yang mempunyai $n$-ach tinggi ingin menyelesaikan tugas dan meningkatkan penampilan mereka.

Selanjutnya McClelland dalam Fauziah (2010) menjelaskan karakteristik orang yang berprestasi tinggi (high achievers) memiliki tiga ciri umum yaitu : (1) sebuah preferensi untuk mengerjakan tugas-tugas dengan derajat kesulitan moderat, (2) menyukai situasi-situasi di mana kinerja mereka timbul karena upayaupaya mereka sendiri, dan bukan karena faktorfaktor lain seperti kemujuran, dan (3) menginginkan umpan balik tentang keberhasilan dan kegagalan mereka, dibandingkan dengan mereka yang berprestasi rendah.

Sebagian besar perilaku diwarnai oleh adanya motivasi tertentu, misalnya mengapa seseorang pergi kuliah? Jawabannya akan berkaitan dengan motivasi, misalnya ingin belajar, ingin mendapatkan pendidikan yang lebih tinggi dan sebagainya. Pada umumnya yang mendorong untuk kuliah ini merupakan kombinasi dari berbagai macam motif tersebut.

Mengenai motivasi, Sanjaya (2008) mengatakan dilihat dari sifatnya motivasi dapat dibedakan antara motivasi intrinsik dan motivasi ekstrinsik. Motivasi intrinsik adalah motivasi yang muncul dari dalam diri individu, misalkan siswa belajar karena didorong oleh keinginannya sendiri menambah pengetahuan, atau seseorang berolahraga tenis karena memang ia mencintai olahraga tersebut. Dengan demikian, dalam motivasi intrinsik tujuan yang ingin dicapai ada dalam kegiatan itu sendiri.

Selanjutnya, Sardiman menyatakan siswa yang memiliki motivasi intrinsik akan memiliki tujuan menjadi orang yang terdidik, yang berpengetahuan, yang ahli dalam bidang studi tertentu. Satu- satunya jalan untuk menuju ke tujuan yang akan dicapai ialah belajar. Dorongan yang menggerakkan itu bersumber dari pada suatu kebutuhan, kebutuhan yang berisikan keharusan untuk menjadi orang yang terdidik dan berpengetahuan. Jadi, memang motivasi itu muncul dari kesadaran diri sendiri dengan tujuan secara esensial, bukan sekedar simbol dan seremonial.

Dariyo (2003) menjelaskan orang yang memiliki motivasi intrinsik biasanya ditandai dengan usaha kerja keras tanpa dipengaruhi oleh lingkungan eksternal, artinya seseorang akan bekerja secara tekun sampai benar- benar mencapai suatu tujuan yang diharapkan tanpa putus asa walaupun memperoleh hambatan atau rintangan dari lingkungan eksternal.

Sedangkan motivasi ekstrinsik (Sanjaya, 2008) adalah motivasi yang datang dari luar diri. Misalkan siswa belajar dengan penuh semangat karena ingin mendapat nilai yang bagus, seseorang berolahraga karena ingin menjadi juara dalam suatu turnamen. Dengan demikian, dalam motivasi ekstrinsik tujuan yang ingin dicapai berada di luar kegiatan tersebut.

$$
\text { Selanjutnya, Davies }
$$

menjelaskan motivasi intrinsik berhubungan erat dengan kedua kebutuhan tingkat lebih tinggi dari Maslow yaitu kebutuhan penghargaan (sukses, percaya diri, harga diri) dan kebutuhan berusaha (mengembangkan diri), sedangkan motivasi ekstrinsik berhubungan pada tiga jenis kebutuhan tingkat rendah yaitu kebutuhan fisiologis (haus, lapar, sex), kebutuhan keamanan (menyelamatkan jiwa, ketertiban) dan kebutuhan kekerabatan (identifikasi,

Selanjutnya Pintrich dan Schunk (2002) menyatakan motivasi intrinsik mengacu pada motivasi yang terlibat dalam kegiatan untuk kepentingan diri sendiri. Orang-orang yang memiliki motivasi intrinsik, akan bekerja pada tugas sebab menemukan sesuatu yang menyenangkan. Partisipasi tugas imbalan sendiri dan tidak bergantung pada penghargaan eksplisit atau kendala eksternal lainnya. Sebaliknya, motivasi ekstrinsik adalah motivasi yang terlibat dalam kegiatan sebagai sarana untuk mencapai tujuan. Individu denganmotivasi ekstrinsik bekerja pada tugas karena mereka percaya bahwa partisipasi akan menghasilkan hasil yang diinginkan seperti hadiah, pujian guru, atau menghindari hukuman.

Rumusan masalah dalam penelitian ini adalah sebagai berikut: (1) Apakah hasil belajar geografi siswa yang diajarkan dengan menggunakan media pembelajaran peta lebih tinggi daripada siswa yang diajarkan dengan menggunakan media pembelajaran globe?; (2) Apakah hasil belajar geografi siswa yang memiliki motivasi berprestasi tinggi lebih tinggi daripada siswa yang memiliki motivasi berprestasi rendah?; dan (3) Apakah terdapat interaksi antara media pembelajaran dan motivasi berprestasi siswa terhadap hasil belajar geografi?

\section{METODE}


Penelitian ini dilakukan di SMP Negeri 1 Singkil dan SMP Negeri 2 Singkil Kecamatan Singkil Kabupaten Aceh Singkil Provinsi Aceh. Populasi dalam penelitian ini adalah seluruh siswa kelas VIII SMP Negeri 1 Singkil dan siswa kelas VIII SMP Negeri 2 Singkil. Jumlah siswa kelas VIII SMP Negeri 1 Singkil berjumlah 94 orang terdiri dari tiga kelas. Sedangkan siswa kelas VIII SMP Negeri 2 Singkil berjumlah 61 orang siswa yang tersebar dalam 2 kelas. Setiap kelas dalam populasi diasumsikan memiliki karakteristik yang sama, dimana tidak terdapat siswa yang pernah tinggal kelas, usia rata- rata yang tidak jauh berbeda secara signifikan, dan menggunakan kurikulum pendidikan yang sama.

Teknik pengambilan sampel dalam penelitian ini yaitu melalui pengampilan sampel secara acak kelas (cluster random sampling). Metode yang diterapkan dalam penelitian ini adalah Quast Experiment (eksperimen semu). Dalam penelitian ini dibedakan atas dua kelompok perlakuan yaitu kelompok I merupakan kelompok perlakuan yang diajarkan dengan media pembelajaran peta, sedangkan kelompok II merupakan kelompok perlakuan yang diajarkan dengan media pembelajaran globe.

Penelitian ini merupakan penelitian eksperimen semu (Quasi Experiment) yang melibatkan dua variabel bebas dan satu variabel terikat. Desain penelitian yang digunakan adalah desain faktorial $2 \times 2$, seperti tertera pada tabel 1 di bawah ini.

Tabel 1. Desain Faktorial 2x2

\begin{tabular}{|c|c|c|}
\hline Tinggi $\left(\mathrm{B}_{1}\right)$ & $\mathrm{A}_{1} \mathrm{~B}_{1}$ & \\
\hline Rendah $\left(\mathrm{B}_{2}\right)$ & $\mathrm{A}_{1} \mathrm{~B}_{2}$ & \\
\hline
\end{tabular}

Sesuai dengan masalah penelitian yang dirumuskan, teknik yang dipakai dalam menganalisis data untuk melihat pengaruh media pembelajaran dan motivasi berprestasi terhadap hasil belajar adalah analisis varians (Anava). Sebelum analisis data dilakukan dengan Anava terlebih dahulu dilakukan uji persyaratan analisis yaitu uji normalitas dan homogenitas data penelitian. Untuk menguji normalitas data digunakan uji Liliefors dan untuk menguji homogenitas data digunakan uji Barllet. Jika ada interaksi antara media pembelajaran dan motivasi berprestasi terhadap hasil belajar geografi maka analisis dilanjutkan dengan menggunakan uji Scheffe untuk mengetahui perbedaan hasil belajar antara kelompok.

Untuk keperluan pengujian hipotesis sebagaimana yang telah dirumuskan sebelumnya maka dirumuskan hipotesis statistik yang akan diuji, sebagai berikut:

1. $\mathrm{H}_{0}: \mu \mathrm{A}_{1}=\mu \mathrm{A}_{2}$

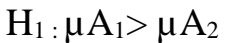

2. $\mathrm{H}_{0}: \mu \mathrm{B}_{1}=\mu \mathrm{B}_{2}$

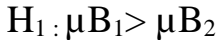

3. $\mathrm{H}_{0}: \mathrm{A}>\langle\mathrm{B}=0$

$\mathrm{H}_{1}: \mathrm{A}><\mathrm{B} \neq 0$

\section{HASIL DAN PEMBAHASAN \\ Hasil}

Hipotesis pada penelitian ini diuji dengan menggunakan analisis varians (ANAVA) dua jalur dengan faktorial $2 \times 2$. Rangkuman data hasil perhitungan analisis MedideBemped ajaman diAihat pada tabe1 2 2. berikut. Media Globe $\left(\mathrm{A}_{2}\right)$

Tabel 2. Rangkuman Hasil ANAVA Faktorial 2 x 2

\begin{tabular}{|l|c|c|c|c|c|}
\hline \multicolumn{1}{|c|}{ Sumber Varians } & $\mathbf{d k}$ & $\mathbf{J K}$ & $\mathbf{R J K}$ & $\mathbf{F}_{\text {hitung }}$ & $\mathbf{F}_{\text {tabel(1:56) } \boldsymbol{a}=\mathbf{0 , 0 5}}$ \\
\hline Media Pembelajaran ( A) & 1 & 30,81 & 30,81 & 5,94 & 4,02 \\
Motivasi Berprestasi ( B) & 1 & 841,99 & 841,99 & 162,23 & 4,02 \\
Interaksi (AxB) & 1 & 73,1 & 73,1 & 14,08 & 4,02 \\
Galat & 56 & 291,08 & 5,19 & - & \\
\hline \multicolumn{1}{|c|}{ Jumlah } & $\mathbf{5 9}$ & $\mathbf{1 2 3 6 , 9 8}$ & $\mathbf{9 5 1 , 0 9}$ & - & - \\
\hline
\end{tabular}


Dengan demikian dapat digambarkan bentuk interaksi antara media pembelajaran dan motivasi berprestasi terhadap hasil belajar Geografi seperti gambar 4.9 berikut ini.

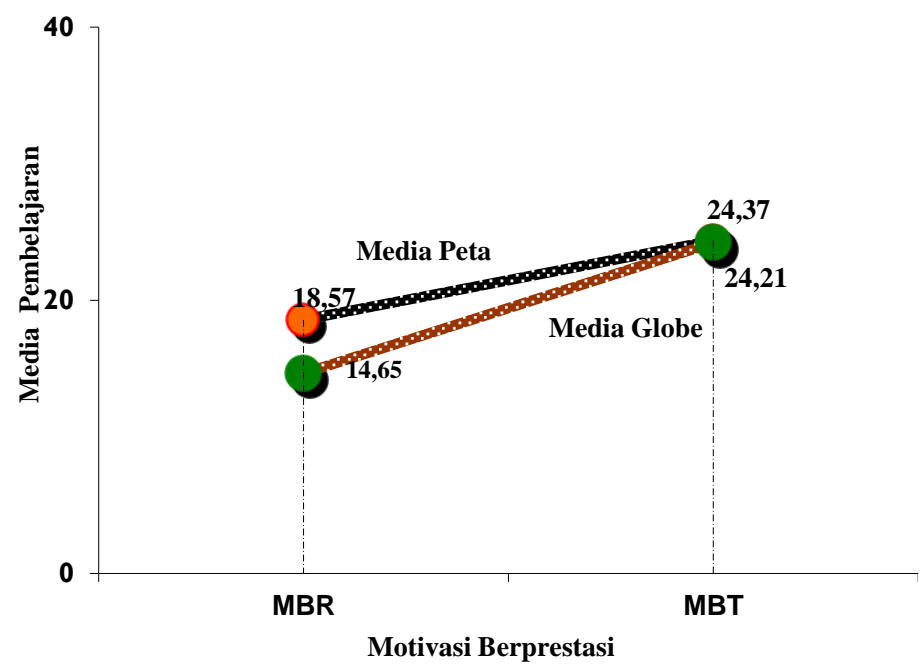

Gambar 1. Interaksi Antara Media Pembelajaran dan Motivasi Berprestasi Terhadap Hasil Belajar

Di antara berbagai perbandingan yang ada, untuk mengetahuinya perlu dilakukan uji lanjut dengan menggunakan uji Scheffe. Dari hasil perhitungan dapat dirangkum seperti pada tabel 3 berikut.

Tabel 3. Rangkuman Hasil Uji Lanjut Dengan Uji Scheffe

\begin{tabular}{|c|c|c|c|c|}
\hline \multicolumn{2}{|c|}{ Hipotesis Statistik } & $\mathbf{F}_{\text {hitung }}$ & $\begin{array}{c}\mathbf{F}_{\text {tabel(3,56) }}(\boldsymbol{\alpha}= \\
\mathbf{0 , 0 5})\end{array}$ & Kriteria \\
\hline $\mathrm{H}_{0}: \mu \mathrm{A}_{1} \mathrm{~B}_{1}=\mu \mathrm{A}_{1} \mathrm{~B}_{2}$ & $\mathrm{H}_{1}: \mu \mathrm{A}_{1} \mathrm{~B}_{1}>\mu \mathrm{A}_{1} \mathrm{~B}_{2}$ & 48,61 & 2,78 & Signifikan \\
$\mathrm{H}_{0}: \mu \mathrm{A}_{1} \mathrm{~B}_{1}=\mu \mathrm{A}_{2} \mathrm{~B}_{2}$ & $\mathrm{H}_{1}: \mu \mathrm{A}_{1} \mathrm{~B}_{1}>\mu \mathrm{A}_{2} \mathrm{~B}_{2}$ & 126,82 & 2,78 & Signifikan \\
$\mathrm{H}_{0}: \mu \mathrm{A}_{2} \mathrm{~B}_{1}=\mu \mathrm{A}_{2} \mathrm{~B}_{2}$ & $\mathrm{H}_{1}: \mu \mathrm{A}_{2} \mathrm{~B}_{1}>\mu \mathrm{A}_{2} \mathrm{~B}_{2}$ & 129,73 & 2,78 & Signifikan \\
$\mathrm{H}_{0}: \mu \mathrm{A}_{2} \mathrm{~B}_{1}=\mu \mathrm{A}_{1} \mathrm{~B}_{2}$ & $\mathrm{H}_{1}: \mu \mathrm{A}_{2} \mathrm{~B}_{1}>\mu \mathrm{A}_{1} \mathrm{~B}_{2}$ & 48,84 & 2,78 & Signifikan \\
$\mathrm{H}_{0}: \mu \mathrm{A}_{1} \mathrm{~B}_{2}=\mu \mathrm{A}_{2} \mathrm{~B}_{2}$ & $\mathrm{H}_{1}: \mu \mathrm{A}_{1} \mathrm{~B}_{2}>\mu \mathrm{A}_{2} \mathrm{~B}_{2}$ & 20,62 & 2,78 & Signifikan \\
$\mathrm{H}_{0}: \mu \mathrm{A}_{1} \mathrm{~B}_{1}=\mu \mathrm{A}_{2} \mathrm{~B}_{1}$ & $\mathrm{H}_{1}: \mu \mathrm{A}_{1} \mathrm{~B}_{1}>\mu \mathrm{A}_{2} \mathrm{~B}_{1}$ & 0,04 & 2,78 & Tidak Signifikan \\
\hline
\end{tabular}

\section{Pembahasan}

Geografi adalah disiplin ilmu yang mengkaji tentang fenomena permukaan bumi. Seperti yang diungkapkan oleh Bintarto dalam Khosim (2007:5) Geografi pada dasarnya merupakan ilmu yang mencitrakan, menerangkan sifat-sifat bumi, menganalisis gejala-gejala alam dan gejala-gejala sosial, serta mengkaji corak yang khas tentang kehidupan dari unsur-unsur bumi dalam ruang dan waktu. Berdasarkan pengertian diatas dapat dikatakan bahwa geografi adalah ilmu penetahuan yang menggambarkan, melukiskan, atau mendeskripsikan hal-hal yang berkitan dengan persamaan dan perbedaan, baik yang terdapat didaratan, lingkungan perairan, lingkungan udara, maupun lingkungan hidup.
Menurut Robert (2011), peta dan globe sangat diperlukan dalam pembelajaran. Peta dan globe masing-masing memiliki kekuatan dan kelemahan tersendiri. Globe memberikan representasi visual yang cukup layak permukaan bumi, ukuran relatif dan bentuk dari benua bersama dengan posisi mereka. Bola yang bulat mengajar siswa fakta yang sangat penting tentang dunia dan kesempatan untuk mempelajari pelajaran tentang kepastian ilmiah. Globe tidak menimbulkan distorsi dari ukuran dan bentuk benua seperti beberapa peta lakukan. Ini adalah masalah ketika mencoba untuk mewakili bumi bulat pada selembar kertas yaitu peta, maka globe sendiri memiliki keterbatasan. Globe hanya memberikan informasi umum dan umumnya tidak 
memberitahukan topografi atau tingkat yang berbeda dari pegunungan. Kita perlu tahu apakah ada gunung dan jika ada perbedaan ketinggian dan sebagainya. Globe memberi kesan yang salah tentang kelengkungan bumi karena jari-jari bola dunia jauh kurang dari jarijari bumi, sehingga menciptakan beberapa distorsi. Peta pada sisi lain dapat dibuat dalam skala apa pun. Peta dapat memberikan informasi sangat rinci termasuk ketinggian, vegetasi dan jalan. Data topografi atau kontur tanah yang dapat disediakan lebih detail pada peta dari globe.

Pembelajaran dengan menggunakan media pembelajaran peta lebih baik karena siswa lebih aktif mengikuti pelajaran. Penggunaan media peta dalam pembelajaran akan membentuk mental map dan cognitive map sehingga siswa dapat membaca dan memahami berbagai peristiwa alam dan kehidupan di muka bumi. Hal ini dikarenakan ketika siswa menggunakan media peta maka secara langsung terjadi interaksi antara siswa dengan media peta. Sumaatmadja (2001) mengatakan kesadaran dan penghayatan anak didik terhadap gejala dan permasalahan yang terjadi dalam kehidupan di permukaan bumi juga dapat terbina pada diri mereka melalui pemanfaatan peta. Dengan demikian, akan terbina kemampuan memanfaatkan sumber daya lingkungan secara rasional sesuai dengan tingkat kualitas kehidupan dan kualitas lingkungannya.

Berbeda dengan pembelajaran yang menggunakan media globe, siswa kurang aktif karena globe tidak dapat memberi keterangan yang rinci tentang keadaan bumi dan membingungkan siswa. Hampir tidak ada interaksi siswa dengan media. Media juga tidak memberikan reaksi terhadap aksi yang dilakukan siswa. Dengan demikian siswa cepat merasa bosan dan tidak terbangun ide-ide yang baru serta kreatifitas dalam menganalisis materi pelajaran. Suharyono dan Amien (1994) menjelaskan ada beberapa kelemahan dari globe yaitu (1) globe kurang praktis dan membingungkan untuk kepentingan pejelajahan bumi, (2) gambar yang kurang jelas dan terlalu kecil, dan (3) tidak punya skala perbandingan yang sesungguhnya karena tanpa skala kita tidak tahu berapa perbandingan yang buatan dengan yang asli. Nilai rata-rata hasil belajar siswa yang diajar dengan menggunakan media peta lebih tinggi dengan nilai rata-rata hasil belajar siswa yang diajar dengan menggunakan media globe. Hasil penelitian ini membuktikan bahwa hasil belajar dengan menggunakan media peta lebih sesuai untuk kompetensi bidang studi geografi.

Motivasi berprestasi menyebabkan kecenderungan dalam diri seseorang untuk mencapai prestasi maksimal, usaha serius serta giat untuk mencapai keberhasilan dalam segala aktivitas. Demikian pula halnya dalam kegiatan belajar, dibutuhkan motivasi berprestasi yang tinggi dalam diri siswa yang menjadi pendorong untuk terus belajar dan meningkatkan kemampuan individual. Sebagai daya penggerak dalam diri untuk memperoleh keberhasilan dalam proses pembelajaran maka dapat dibedakan siswa yang memiliki motivasi berprestasi tinggi dan siswa yang memiliki motivasi berprestasi rendah. Siswa yang bermotivasi tinggi pasti terlihat berbeda jika dibandingkan dengan siswa yang bermotivasi rendah.

Di dalam belajar, faktor motivasi berprestasi merupakan satu faktor psikologis yang dimiliki oleh seorang siswa. Faktor motivasi terhadap suatu mata pelajaran akan mempengaruhi terhadap pencapaian hasil belajarnya. Siswa yang cenderung memiliki motivasi berprestasi yang tinggi terhadap suatu mata pelajaran akan mencapai hasil belajar yang lebih tinggi dibandingkan dengan siswa yang memiliki motivasi berprestasi rendah.

Demikian pula dalam pembelajaran Geografi, siswa dengan motivasi berprestasi tinggi memiliki kecenderungan untuk belajar lebih giat, memaksimalkan segala sumber belajar yang ada di sekitarnya. Apabila seorang siswa memiliki motivasi berprestasi tinggi, maka memiliki kecenderungan akan dapat menyelesaikan tugas dengan baik. Berdasarkan dari motif tersebut maka siswa lebih giat dalam melakukan belajar dan dengan demikian akan mempermudah dalam penguasaan materi geografi.

Secara psikologis pembelajaran geografi membutuhkan suatu motivasi berprestasi yang tinggi, hal ini disebabkan siswa dihadapkan pada suasana belajar yang harus memecahkan masalah yang ada, bagaimana cara dia mengasah keterampilan penalaran dan menggunakan peta dan globe dengan baik. Sebagai contoh, siswa dapat menghitung seberapa jauh jarak perpustakaan dari sekolah atau rumah. Hal ini membangun kepercayaan siswa untuk dalam kemampuannya merumuskan solusi. Apabila motivasi berprestasinya rendah maka siswa tersebut tidak akan dapat mengatasinya dengan baik. Intinya, 
bahwa seseorang dengan motivasi berprestasi tinggi memiliki daya dorong yang kuat dari dalam dirinya untuk terus meningkatkan kemampuan, jika dalam belajar bagaimana belajar diupayakan untuk mencapai hasil belajar maksimal.

Pada siswa yang memiliki motivasi berprestasi rendah pada dasarnya dalam mengikuti proses belajar akan berbeda dengan mereka yang memiliki tingkat motivasi berprestasi tinggi. Hal tersebut dikarenakan oleh faktor dorongan yang timbul dari diri mereka rendah yang mengakibatkan mengendornya motivasi untuk melatih kemampuan mereka, sehingga akan memberikan dampak yang negatif terhadap hasil belajar mereka.

Siswa yang memiliki motivasi berprestasi yang rendah, tidak memiliki daya pendorong yang kuat dari dalam dirinya sehingga tidak berusaha untuk mencapai hasil yang maksimal dalam usaha belajarnya. Artinya, hal ini membuktikan bahwa siswa yang memiliki motivasi berprestasi tinggi akan mempunyai kinerja yang lebih baik dibandingkan dengan siswa yang memiliki motivasi berprestasi rendah.

Siswa yang memiliki motivasi berprestasi tinggi cenderung memiliki hasil belajar yang lebih tinggi dibandingkan dengan siswa yang memiliki motivasi berprestasi rendah. Hasil penelitian ini dapat menjelaskan bahwa motivasi berprestasi yang merupakan salah satu karakteristik siswa dapat mempengaruhi hasil belajar. Siswa dengan motivasi berprestasi tinggi cenderung untuk belajar lebih giat untuk mencapai hasil belajar yang maksimal, berbeda dengan siswa yang memiliki motivasi berprestasi rendah.

Hal ini sejalan dengan pendapat dari Bloom (1986) yang menyebutkan bahwa salah satu faktor yang mempengaruhi hasil belajar siswa adalah karakteristik siswa. Hasil penelitian ini juga relevan dengan hasil penelitian dari Pulungan (2005) yang memberi kesimpulan terhadap hubungan yang signifikan antara motivasi berprestasi dengan perolehan hasil belajar Fisika. Berdasarkan hasil penelitian ini serta hasil penelitian terdahulu, jelas menyebutkan bahwa faktor motivasi berprestasi berpengaruh terhadap hasil belajar.

Hasil belajar siswa dipengaruhi oleh faktor internal (dari dalam diri siswa) serta faktor eksternal atau faktor yang berasal dari luar diri siswa. Faktor luar yang salah satunya adalah media pembelajaran turut mempengaruhi kualitas pembelajaran dimana guru adalah yang paling bertanggungjawab didalamnya untuk keberhasilan proses belajar. Kemudian faktor internal dalam hal ini adalah motivasi berprestasi siswa. Hasil penelitian memperlihatkan bahwa terdapat interaksi antara media pembelajaran dan motivasi berprestasi terhadap hasil belajar geografi pada siswa SMP Negeri Kecamatan Singkil. Temuan dalam penelitian ini adalah: (a) hasil belajar geografi siswa yang diajar dengan media pembelajaran peta lebih tinggi dari pada hasil belajar geografi siswa yang diajar dengan media pembelajaran globe. (b) hasil belajar siswa yang diajar dengan media pembelajaran peta dan globe tidak berbeda secara signifikan baik pada kelompok siswa yang mempunyai motivasi berprestasi tinggi, (c) terdapat perbedaan hasil belajar geografi siswa yang memiliki motivasi berprestasi rendah yang diajar dengan media pembelajaran peta dan media globe.

Hasil penelitian mengemukakan bahwa penggunaan media pembelajaran globe memberikan pengaruh lebih baik bila diterapkan pada kelompok siswa yang memiliki motivasi berprestasi tinggi dibandingkan bila diterapkan pada kelompok siswa yang memiliki motivasi berprestasi rendah. Bagi siswa yang memiliki motivsai berprestasi tinggi, penggunaan media globe adalah suatu tantangan tersendiri untuk lebih memahami dunia dalam skala kecil dan dapat menimbulkan keingitahuan siswa sehingga mereka berusaha lebih keras untuk belajar dan mencapai sukses.

Sedangkan bagi siswa dengan motivasi berprestasi rendah menggunakan globe merupakan hal yang rumit dan membingungkan untuk dipahami maknanya. Sebagai contoh, jika guru memberikan tugas untuk mencari letak Provinsi Aceh, maka jika dengan media globe ia harus memutar bola dunia tersebut untuk menemukan kawasan tersebut. Gerakan ini membuat sulit untuk menilai jarak, dan beberapa pemahaman visual yang hilang. Keadaan ini, akan membuat siswa dengan motivasi rendah cenderung kehilangan motivasi dan akan merasa jenuh dengan materi pelajaran, pada akhirnya mempengaruhi hasil belajar geografi siswa tersebut.

Dari hasil penelitian dan uji scheffe juga diperoleh bahwa penggunaan media pembelajaran tidak selamanya berpengaruh terhadap hasil belajar siswa, hal tersebut dapat dilihat bahwa hasil belajar siswa dengan motivasi berprestasi tinggi yang diajar dengan 
menggunakan media pembelajaran peta tidak jauh beda dengan hasil belajar siswa dengan motivasi berprestasi tinggi yang diajar dengan menggunakan media pembelajaran globe.

Menurut Hollowell (2011), dengan mempelajari peta dan globe siswa dapat lebih memahami, fitur ekonomis politik dan sosial suatu negara, selain memperoleh pengetahuan geografis. Studi tentang peta dan globe juga meningkatkan motivasi belajar siswa yang akan membantu siswa saat mereka maju di sekolah.

Ketika siswa mengetahui bagaimana membaca peta, mereka akan dapat melihat dunia dalam cahaya baru. Peta menyediakan lebih dari sekedar lokasi. Membaca peta dapat memberikan siswa rasa perspektif ketika mereka melihat bahwa mereka adalah bagian dari dunia yang lebih besar, yang bisa menanamkan keinginan untuk mempelajari lebih lanjut tentang tempat-tempat pada peta.

Peta membantu siswa meningkatkan pemecahan masalah dan keterampilan penalaran. Sebagai contoh, siswa dapat menghitung seberapa jauh perpustakaan dari sekolah atau rumah. Mereka juga dapat merumuskan rute termudah dan tercepat untuk melakukan perjalanan ke tempat-tempat liburan favorit. Ini membangun siswa swasembada dan kepercayaan dalam kemampuan mereka untuk merumuskan solusi.

Dengan mempelajari peta siswa dapat belajar banyak tentang negara, termasuk informasi tentang bentuk tanah, badan air, sumber daya alam dan iklim. Sebagian besar dari geografi menyangkut aspek teknis konstruksi peta. Siswa akan belajar tentang simbol-simbol dan alat-alat dari peta, seperti kompas bangkit, kunci dan judul yang membantu membedakan satu dari yang lain peta.

Selain itu, siswa mendapatkan rasa yang kuat dari sejarah tempat dengan mempelajari peta. Peta harus digambar ulang secara berkala untuk mencerminkan perubahan yang dihasilkan dari perang, politik dan konflik internal. Dengan mempelajari peta lama dan baru, siswa dapat melihat transformasi ini. Sebagai contoh, mereka dapat belajar tentang sejarah Amerika Serikat dengan mempelajari peta dari masa kolonial ke era pasca perang sipil. Siswa juga dapat melihat bagaimana Eropa telah berubah beberapa kali selama abad terakhir sebagai daerah memperoleh kemerdekaan atau menjadi bagian dari negara lain.
Siswa dapat memperkuat keterampilan menulis dengan membandingkan fitur dari berbagai negara bahwa mereka telah belajar dari mempelajari peta. Mereka juga dapat meningkatkan keterampilan matematika dengan grafik suhu rata-rata dan jumlah curah hujan dari peta fisik. Karena ada banyak jenis peta, siswa dapat belajar untuk mengatur dan mengklasifikasikan data, yang merupakan keterampilan yang berguna untuk setiap mata pelajaran akademis.

Hasil penelitian ini mendukung hasil penelitian yang dilakukan oleh Hadi (2003) yang menyimpulkan bahwa sebelum guru mengajar perlu dilakukan penilaian awal terhadap karakteristik siswa yang akan diajarnya. Dengan demikian hasil belajar yang merupakan perubahan tingkah laku atau kemampuan dalam diri siswa berupa pengetahuan, sikap dan keterampilan yang bersifat efektif, efisien dan mempunyai daya tarik dapat tercapai. Dari uraian diatas, jelas bahwa terdapat interaksi antara media pembelajaran dan motivasi berprestasi terhadap hasil belajar

\section{PENUTUP \\ Simpulan}

Terdapat perbedaan hasil belajar geografi antara siswa yang diajarkan dengan menggunakan media pembelajaran peta dengan siswa yang diajarkan dengan menggunakan media pembelajaran globe. Kelompok siswa yang diajarkan dengan menggunakan media pembelajaran peta memperoleh hasil belajar yang lebih tinggi jika dibandingkan dengan kelompok siswa yang diajarkan dengan menggunakan media pembelajaran globe.

Terdapat perbedaan hasil belajar geografi antara siswa yang memiliki motivasi berprestasi tinggi dan kelompok siswa yang memiliki motivasi berprestasi rendah. Siswa yang memiliki motivasi berprestasi tinggi memperoleh hasil belajar lebih tinggi dibandingkan dengan kelompok siswa yang memiliki motivasi berprestasi rendah.

Terdapat interaksi antara media pembelajaran dan motivasi berprestasi terhadap hasil belajar geografi siswa. Rata- rata hasil belajar geografi yang paling tinggi adalah siswa yang memiliki motivasi berprestasi tinggi yang diajarkan dengan media pembelajaran peta, sedangkan yang paling rendah adalah kelompok siswa motivasi berprestasi rendah yang menggunakan media pembelajaran globe. 


\section{Saran}

1. Penelitian ini masih perlu dikembangkan lebih lanjut pada skala yang lebih luas dengan objek penelitian dan variabel lain. Karena penelitian ini dilakukan di SMP Negeri 1 Singkil dan SMP Negeri 2 Singkil maka disarankan para peneliti lain untuk melakukan penelitian dengan variabel yang sama di SMP Negeri lain dengan kondisi yang berbeda sehingga diperoleh hasil penelitian yang dapat mencerminkan kondisi yang lebih umum.

2. Karakteristik siswa yang dijadikan variabel moderator dalam penelitian ini adalah motivasi berprestasi siswa. Disarankan untuk penelitian lanjutan melibatkan karakteristik siswa yang lain guna melengkapi kajian penelitian ini.

3. Para guru SMP Negeri di Kecamatan Singkil hendaknya selalu berusaha untuk menggunakan media pembelajaran dalam proses belajar mengajar agar hasil belajar siswa lebih meningkat.

4. Para pengelola sarana dan prasarana pembelajaran, agar selalu mengikuti perkembangan media pembelajaran sehingga dapat diterapkan pada pengajaran di kelas, agar hasil belajar siswa lebih baik.

5. Media pembelajaran dan karakteristik siswa merupakan suatu komponen yang dapat menentukan atau mempengaruhi hasil belajar geografi. Oleh karena itu, guru sebagai perancang pengajaran perlu mempertimbangkan karakteristik siswa.

\section{DAFTAR PUSTAKA}

Adiwuyono, N.S. 2008. Teknik Membaca Peta dan Kompas. Bandung : Angkasa.

Anderson, O.W. dan Krathwohl, D.R. 2001. A Taxonomy for Learning, Teaching, and Assessing. New York: Addison Wesley Longman, Inc.

Arsyad, A. 2010. Media Pembelajaran. Jakarta : Rajawali Pers.

Basuki, A.M. 2008. Psikologi Umum. Jakarta : Gunadarma.

Bloom, B.S. (ed.). 1976. Human Characteristics and School Learning. New York: Mc Graw- Hill Book Company.

Cronbach, L.J. 1979. Educational Psychology. New York : Harcourt Brace Jovanovich Inc.

Dalimunthe, C. 2004. Pendidikan Ilmu Sosial/ Wawasan IPS. Medan : Laboratorium
PPKn Fakultas Ilmu Sosial Universitas Negeri Medan.

Dariyo, A. 2003. Psikologi Perkembangan Dewasa Muda. Jakarta : Grasindo.

Depdiknas. 2003. Kurikulum Berbasis Kompetensi $(K B K)$. Jakarta: Departemen Pendidikan Nasional.

Djiwandono, Sri E.W. 2002. Psikologi Pendidikan. Jakarta : Gramedia Widiasarana Indonesia.

Fauziah, A. 2010. Motivasi Berprestasi. (Online).

(http://aliafauziah.blogspot.com/2010/11/motiv asi-berprestasi.html. Diakses pada tanggal 14 April 2011).

Gagne, R. M. \& Briggs, L.J. 1979. Principles of Instructional Design. New York : Holt Rinehart \& Winston.

Gagne, R.M, dkk. 1992. Principle of Instructional Design. For Worth, TX : Harcourt Brace Jovanivich, Publishers.

Gunawan, T. 2004. Fakta dan Konsep Geografi. Bandung : Ganeca Exact.

Gunawan, T. 2003. Peta, Atlas, dan Globe Sebagai Sarana Belajar Geografi. Jakarta : Departemen Pendidikan Nasional.

Hamalik, O. 2006. Proses Belajar Mengajar. Bandung : Bumi Aksara.

Hartono, R. 2010. Kartografi Dasar. Malang : Jurusan Geografi Fakultas Ilmu Sosial Universitas Negeri Malang.

Hidayat, A. 2010. Peta. (Online).

(http://andimanwno.wordpress.com/2010/06/22/ peta/Andi Hidayat Diakses pada tanggal 21 Agustus 2010).

Hilgard, G.H. \& Bower, H.R. (1981). Theories of Learning. Princtice Hall. New York.

Hollowell, K. Pentingnya Penggunaan Maps \& Globes di Sekolah. (Online). (http://www.ehow.com/about_5398493_i mportance-using-maps-globesschools.html\#ixzz2I2nq5S5m. Diakses tanggal 14 Januari 2013).

Khosim, A. 2007, Geografi SMA Kelas XI. Jakarta: Grasindo.

McClelland, David C.,dkk. 1995. The Achievement Motive. New York : Irvington. Inc.

Munawar, I. 2009. Pengertian dan Definisi Hasil Belajar. (Online).

(http://indramunawar.blogspot.com/2009/06/has il-belajar-pengertian-dan-definisi.html. Diakses pada tanggal 21 Agustus 2010). 
Nartakono. 2010. Peningkatan Pembelajaran IPS Melalui Media Peta dan Globe di Kelas VA SD Negeri Kebun Damar Kecamatan Mataram Baru Tahun 2010. (Online).

(http://megaziza.wordpress.com/2010/11/ 14/65/. Diakses tanggal 24 Mei 2011).

Pintrich Paul R. \& Schunk Dale H. 2002. Motivation In Education : Theory, Research, and Application. Columbus, Ohio : Upper Saddle River, New Jersey.

Pulungan, Abdul H. 2005. Pengaruh Metode Pembelajaran Remedial dan Motivasi Berprestasi Terhadap Hasil Belajar Fisika Siswa SMP Negeri 35 Medan. Medan : Tesis UNIMED.

Puskur Balitbang. 2003. Standar Kompetensi Bahan Kajian; Pelayanan Profesional Kurikulum Berbasis Kompetensi. Jakarta : Departemen Pendidikan Nasional.

Prayitno \& Manullang, B (Ed.). 2010. Pendidikan Karakter Dalam Pembangunan Bangsa. Medan : Pasca Sarjana UNIMED.

Ray, Damaiwaty. 2004. Pengaruh Media Pembelajaran dan Gaya Kognitif Terhadap Hasil Belajar Makrame Mahasiswa PGSD UNIMED. Medan : Tesis UNIMED.

Roberts, K. 2011. Apa Keuntungan Apakah Maps Selama Globes? (Online). (http://www.ehow.com/info 8528146 ad vantages-do-maps-over-
globes.html\#ixzz2I2nVMGrr. Diakses tanggal 13 Januari 2013).

Romiszwoski, A.J. 1983. Designing Instructional System. New York : Nicholas.

Sagala, Syaiful. 2007. Konsep dan Makna Pembelajaran. Bandung : Alfabeta.

Sanjaya, W. 2008. Kurikulum dan Pembelajaran: Teori dan Praktek Pengembangan Kurikulum Tingkat Satuan Pendidikan (KTSP). Jakarta : Kencana Prenada Media Group.

Sanjaya, W. 2006. Strategi Pembelajaran Berorientasi Standar Proses Pendidikan. Jakarta : Kencana Prenada Media Group.

Sardiman, A.M. 2009. Interaksi dan Motivasi Belajar Mengajar. Jakarta : Raja Grafindo Persada.

Sardiman, A. 2010. Pengertian Media. (Online).

(http://www.canboyz.co.cc/2010/05/peng ertian-definisi-media.html. Diakses pada tanggal 22 Agustus 2010).

Sugiharto, dkk. 2010. Bahan Kuliah DasarDasar Geografi. Medan : Jurusan Pendidikan Geografi FIS Universitas Negeri Medan.

Syah, M. 2009. Psikologi Belajar. Jakarta : Raja Grafindo Persada.

Walgito, B. 2004. Pengantar Psikologi Umum. Yogyakarta : Andi.

Wardiyatmoko, K. 2009. Ilmu Pengetahuan Sosial Untuk SMP/ MTs Kelas VIII. Jakarta : Erlangga. 